\title{
On the Identification of the Key Factors for a Successful Use of Twitter as a Medium from a Social Marketing Perspective
}

\author{
Ester Guijarro, Cristina Santadreu-Mascarell *D, Beatriz Blasco-Gallego, Lourdes Canós-Darós \\ and Eugenia Babiloni (D)
}

Departamento de Organización de Empresas, Universitat Politècnica de València, 46022 Valencia, Spain; esguitar@doe.upv.es (E.G.); beablag1@alumni.upv.es (B.B.-G.); loucada@omp.upv.es (L.C.-D.); mabagri@doe.upv.es (E.B.)

* Correspondence: crisanma@omp.upv.es

check for updates

Citation: Guijarro, E.;

Santadreu-Mascarell, C.; Blasco-Gallego, B.; Canós-Darós, L.; Babiloni, E. On the Identification of the Key Factors for a Successful Use of Twitter as a Medium from a Social Marketing Perspective. Sustainability 2021, 13, 6696. https://doi.org/ $10.3390 /$ su13126696

Academic Editors:

María-Ángeles Revilla-Camacho,

Dolores Garzón and Carlos

J. Rodríguez-Rad

Received: 27 April 2021

Accepted: 10 June 2021

Published: 12 June 2021

Publisher's Note: MDPI stays neutral with regard to jurisdictional claims in published maps and institutional affiliations.

Copyright: (c) 2021 by the authors. Licensee MDPI, Basel, Switzerland. This article is an open access article distributed under the terms and conditions of the Creative Commons Attribution (CC BY) license (https:// creativecommons.org/licenses/by/ $4.0 /)$.
Abstract: Public administrations are organizations whose mission is to serve the interests of society by providing efficient and sustainable services. Much of the information received from public administrations uses social media due to their versatility and capacity to reach a large number of citizens. Among them, Twitter is the most widely used, especially to disseminate messages with a high social content. This type of messages falls within the discipline of social marketing. However, when public administrations use Twitter for social marketing communication, it is not known which factors are the most decisive to achieve the social objective for which they are issued. This article provides an answer to this question, using the Analytic Network Process Multicriteria method to determine which factors matter and how they are interrelated when issuing social marketing messages through Twitter. The result of this research reveals that from the 22 factors analyzed, the most influential from a social marketing point of view are the average age of population, the existence of a strategic communication plan, the number of tweets and the average number of tweets per day, the number of followers, retweets and mentions, as well as the efficiency of the account.

Keywords: analytical network process; communication strategies; interaction; interrelations; multicriteria decision-making method; public administrations; social marketing; social welfare and sustainability; Twitter

\section{Introduction}

In 2015, the United Nations (UN) [1] adopted a resolution entitled "Transforming our world: the 2030 Agenda for Sustainable Development". According to this agreement, UN Member States adopted the 2030 Agenda for Sustainable Development, which includes 17 Sustainable Development Goals (SDGs) and 169 targets. SDGs have to be achieved by multiple bodies, including governments, public bodies, companies, citizens, etc. As a consequence of the concerns about sustainability, public administrations became aware of the relevance of the information they handled and, fundamentally, that the interaction with citizens allowed the improvement of the design and implementation of public services and policies [2-4]. In this sense, public administrations are aligned toward the promotion of sustainability, defined in the Brundtland Report [5] as a "development that meets the needs of the present without compromising the ability of future generations to meet their own needs". As sustainability involves the correct use of a given resource while minimizing the negative impact on the planet, it is also possible to analyze sustainability as associated with the use of social media and the messages that are transmitted through them [6-8]. Ref. [9] indicates that the evolution of social media in recent years shows that these new media forms were created not only to inform and exchange knowledge but also to achieve a change in social habits as a contribution to the progress of sustainable development. Hence, social media are deemed an essential communication tool for sustainable development [10-12] and for the promotion of behaviors 
conducive to sustainability [13]. Therefore, public organizations are indeed aligned toward the promotion of sustainability through their communication strategies.

In this context, Spanish public administrations use information and information technologies, particularly after the publication of Law 11/2007, to cover the electronic access of citizens to public services. This new paradigm changed from a patrimonial vision, where public administrations were solely responsible for safeguarding and managing information, to a new model, where citizens demand more and more information, transparency and communication strategies from public administrations. It is clear that governments and public bodies in Spain adopted social media as an additional management tool, as they became the ideal medium for internal collaboration [14], knowledge management [15] and, fundamentally, the interrelationship between public institutions and society [16], thereby changing the means of communicating with citizens and adapting to a collaborative and dynamic environment $[17,18]$. Consequently, a high number of public administrations routinely used social media for these purposes [19], yet few public entities had a formal strategy for the management of their social media. Therefore, Spanish public administrations were still in the preliminary phase of their implementation [20]. In fact, other authors agreed on the relevance of the use of social media by public administrations but stressed that there were a number of limitations in their use $[21,22]$ which required research to establish strategies for the implementation and use of social media by public institutions $[20,23,24]$ that are fundamentally based upon citizen participation [25]. While it seemed clear that social media would endure in the day-to-day life of public administrations, the question now was how they should be used to achieve their goal of efficient interrelationships with citizens.

In the literature, we found several approaches for measuring, diagnosing and analyzing the social media of public administrations [26]. Some studies, such as [18], showed success stories of public entities that opted to use social media to improve the communication with citizens and proposed best practice guides. These guides were based not only on the generation of content, but also on the need to monitor effects (i.e., to know what users say and how they react) as well as to evaluate activity through the identification and study of the success factors in the use of social media for a specific purpose. From the extensive range of available social media, Twitter became the digital social tool most used by Spanish public administrations $[19,20]$, delivering public policies on a small scale, reducing the separation between public authorities and the people and facilitating a direct and simple interrelationship between them [27]. Twitter also offered the opportunity to capture what citizens thought about government activity, transmitting their demands and concerns, and thus became a bidirectional social communication channel, especially to promote social welfare and sustainability.

Within the public bodies that used Twitter to disseminate messages of a social nature in Spain, the state security forces stood out for their activity and experience. There were many Spanish state security forces with Twitter accounts, and some of them were the subject of other studies [28,29]. In 2014, the Spanish National Police received the Citizenship Award for Quality and Innovation in Public Management in recognition of their innovative practice in the provision of services and systems to relate to citizens and users [30]. There are several authors [31-39] that focus their research, on the one hand, on carrying out a literature review of the communication strategy (use or scope, among others) of state security forces and, on the other hand, on analyzing and sharing the reasons for their success, with differing perspectives such as linguistics, emotions, content, parameters or variables, informing and warning. All of them show that the use of social media, and especially Twitter, captured the public's attention to the point of placing them in the top positions worldwide in terms of the number of followers.

These public bodies saw Twitter as a powerful tool for launching their social messages, using it as a communication channel that allowed them to reach many users instantly and directly, thus achieving an impact on users for the sake of general welfare. These organizations used Twitter as their social marketing communication tool seeking to influence the behavior of people in a way that was beneficial to society [40,41]. According to [42], 
social marketing can be defined as the use of principles and techniques to influence a target audience to voluntarily accept, reject, modify or abandon a behavior for the benefit of individuals, groups or society as a whole. Some examples of social marketing messages are the promotion of given attitudes regarding road safety, such as putting on a seat belt when driving a car or crossing over a traffic light when we are pedestrians. However, although the content of the message belonged to the field of social marketing, the key issue is to determine from a social point of view which of the factors involved in Twitter communication most affect the success of one profile. The answer lies in the identification of the factors and their relationships and the pattern of their influence on the achievement of the organization's social communication objective.

Bearing this idea in mind, the objective of this paper is, firstly, to identify the factors involved in the social marketing communication of a Twitter profile and, secondly, to establish and model the relationships between these factors in order to determine which and to what extent they serve to guarantee the success of a profile when its objective is to positively influence the behavior of citizens, i.e., from a social marketing perspective. For this purpose, profiles of state security forces have been selected for this research given the special characteristics of these profiles, previously discussed, and their potential for determining social and sustainable marketing strategies. As a fresh approach, this study uses a Multi-Criteria Decision-Making (MCDM) method and, more specifically, the Analytic Network Process (ANP) to reach its objective, since this method offers a rational and objective tool to understand and model complex decision processes [43].

\section{Materials and Methods}

MCDM has been applied to several marketing problems. The strength of this method lies in the possibility of solving complex decision problems in which it is critical to determine which criteria are truly important and to what extent. For example, Ref. [44] conducted a comprehensive study of a large-scale Twitter dataset reflecting the preferences (e.g., interests, sentiments, trends, influences) of customers by using the Technique for Order of Preference by Similarity to Ideal Solution (TOPSIS) MCDM method. Moreover, Ref. [45] used a hybrid MCDM method that included the Decision Making Trial and Evaluation Laboratory (DEMATEL) method to assess the dimensions that influenced online reputation management, and [46] combined DEMATEL with two MCDM methods, including Multicriteria Optimization and Compromise Solution (VIKOR, after the original Serbian) and Analytic Network Process (ANP), in order to identify the relationships between the influential factors in brand management. On the other hand, Ref. [29] employed the Analytic Hierarchical Process (AHP) method to identify the relevant variables that affected communication by analyzing four law enforcement profiles.

However, our study used, for the first time in the literature, the ANP method [47] in the context of social marketing to identify strategic factors that influence human behavior when using social media as communication tool. ANP presents several advantages among other MCDM methods. Firstly, it allows for the incorporation of complex human judgments into the problem [48]. Secondly, ANP models the problem as a network that provides a realistic representation of relationships between factors. Thirdly, ANP allows for the incorporation of different types of information, both qualitative and quantitative [49]. Finally, the inherent degree of subjectivism and inconsistency of judgments that takes place in real situations is overcome by ANP through the measurement of the reliability of expert answers by calculating a consistency index [50].

When applying ANP, the first step is to present the problem as a network. A network model is made up of elements or nodes (either the alternatives to be decided or the decision criteria) that are grouped into clusters. Therefore, an element of a cluster in the network may have influence on some or all the elements of that same cluster or on some element of another cluster in the network. This step is the most creative and, perhaps, the most important, as it forms the basis for the rest of the steps. The quality of the network depends to a large extent on the degree of knowledge of the problem, because if all the 
elements influencing the problem are not considered or the dependencies are not correctly established, the results obtained may lead to erroneous decisions. In order to present the model as a network it is necessary to: (1) identify all the elements of the network (both the criteria and the alternatives), (2) group those elements with common characteristics into clusters, and (3) analyze the relationships between the elements of the network by means of an interfactor dominance matrix. As a result, a correlation matrix is obtained, which collects the relationships between all the elements of the model. Note that in the network models using the ANP method the alternatives constituted an additional cluster of the model on which all criteria have an influence and which influences, in turn, all criteria.

Once the model has been built, the relative importance of the elements must be determined by using paired comparisons between the elements of the model via simple structured questions that allow for the incorporation of the judgment of experts into the model. Thus, the expert must answer the question "which element has the greatest influence on the model?" To resolve this question, this study used the comparison scale proposed by Ref. [51], which had been widely used and theoretically and empirically validated. This scale ranges from 1 to 9 , and each value is assigned a verbal label, so that it is more understandable and easier to use by any type of decision-maker. This allows for the incorporation of the subjectivity, experience, and knowledge of the expert into the decision process. In this scale, the expert must indicate whether two elements are equally important (assigning a value of 1 to this situation in the model), whether one element is of moderate importance compared to another (assigning a 3), whether one element is of high importance compared to another (assigning a 5), whether one element is of very high importance compared to another (assigning a 7) or, finally, whether one element is significantly more important than another (assigning a 9). If the comparison is the opposite (one element is less important than the other), Saaty's scale uses the reciprocal values $(1 / 9$, $1 / 7,1 / 5$ or $1 / 3)$. Given the subjectivism of the process, ANP measures the consistency of the judgments made by the expert by calculating the consistency ratio $(C R)$, defined as the quotient between the consistency index $(C I)$ and the random consistency index $(R I)$, i.e.,: $C R=C I / R I$, which measures the ratio between the consistency achieved by the matrix studied and the average consistency index that would be achieved if a matrix of the same dimension were completed randomly using the values of Saaty's scale. Acceptable CR values must be less than 0.1 .

Once the relative importance of the elements of the clusters, the clusters themselves, and the alternatives have been determined, the following step is to calculate the weighted supermatrix and the limit supermatrix of the network. As a result, we obtain the relative weight of each element. In this way, it is possible to determine which alternative is better and which factors are more important in the model, having included the dependency relationships existing between the elements of the network.

The application of ANP summarized above has been applied to our problem according to the following steps (see Figure 1). The first step consisted of selecting the elements of the model: decision criteria and alternatives. To this end, we reviewed the existing literature, and an expert in social media communication validated the selection of criteria, eliminating some and incorporating others. After that, the time period for the analysis was chosen. This period was set at six months, a sufficiently long period to have an overall view of the profiles and thus dampen the effect of possible deviations in the model resulting from specific public events generating an intense reaction across the social media. The analysis period for the study lasted from 1 October 2017 to 31 March 2018.

The second step was to obtain data for each of the selected criteria. This task was performed using the Twitonomy and Tinfoleak tools. Note that obtaining information from accounts of other owners is complex and standard tools on the market limit searches to a fixed number of tweets published, which may introduce bias in the data. For example, a profile that gets one hundred retweets in two days would have the same activity and impact data as a profile that gets one hundred retweets in two months. For this reason, 
Twitonomy and Tinfoleak were used, since both tools allow for the analysis of the activity of several profiles for the same time period.

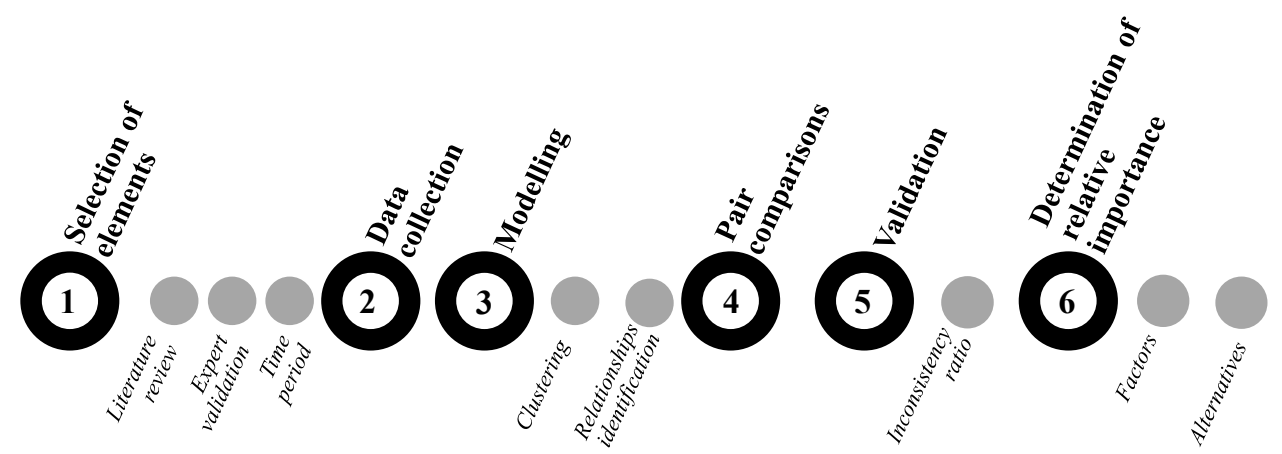

Figure 1. Methodological scheme of this study based on the ANP method.

Parallel to the collection of information, the third step consisted of modeling the problem by grouping the criteria into four clusters and determining the relationships between their elements. Once all the relationships were identified, in the fourth step, the expert assessed each pair of elements in which there was a relationship through the paired comparison between elements using the comparison scale proposed by Ref. [51].

The validation of the model took place on the fifth step, where the research team calculated the consistency ratios. In those cases where an inconsistency was detected, the expert repeated the assessment. In this study, inconsistencies appeared in five comparison matrices, and the expert reevaluated them.

The sixth and last step was the building of the supermatrices, whose convergence determines the importance of each element of the model.

\section{Results}

\subsection{Modeling the Problem}

According to the methodology described above, the first step is to identify the criteria and the alternatives, group them into clusters and analyze their relationships to represent the network of the model.

Regarding the alternatives, this study focused on the profiles of law enforcement agencies because they represented public bodies that used Twitter almost exclusively to launch social marketing campaigns, taking into account social welfare and sustainability in the launched messages. In addition, alternatives with different geographical coverage were chosen in order to have a more representative sample. Specifically, the police profiles studied were: Europol (@europol_eu), at the European level, the National Police (@policia), at the Spanish state level, the Mossos de Esquadra (@mossos), at the Catalonian regional level, and the London Metropolitan Police (@metpoliceuk), at the local level.

For the selection of criteria, after the literature review and the validation of the communication expert, 22 criteria remained, which were grouped by the expert into four clusters: "Social Group and Technology", "Organization", "Account Activity" and "Account Impact". Table 1, below, presents the 22 criteria grouped into clusters and describes the meaning of each along with the source from which the information was obtained. 
Table 1. The description of the criteria included in the model, the cluster to which they belong and the data source.

\begin{tabular}{|c|c|c|}
\hline Cluster/Criterion & Description & Source \\
\hline \multicolumn{3}{|c|}{ SOCIAL GROUP AND TECHNOLOGY } \\
\hline Number of residents & $\begin{array}{l}\text { Population in the geographic area corresponding to each profile in the } \\
\text { year } 2017\end{array}$ & INE/EUROSTAT \\
\hline Average age of population & $\begin{array}{l}\text { Average age of the inhabitants of the corresponding geographic area in } \\
\text { the year } 2017\end{array}$ & INE/EUROSTAT \\
\hline Households with internet access & $\begin{array}{l}\text { Percentage of households with Internet access over the total percentage } \\
\text { of households in the corresponding geographic area for the year } 2017\end{array}$ & INE/EUROSTAT \\
\hline \multicolumn{3}{|c|}{ ORGANIZATION } \\
\hline Strategic communication plan & $\begin{array}{l}\text { Existence or non-existence of an organizational strategic communication } \\
\text { plan that establishes guidelines for social network use }\end{array}$ & Organization \\
\hline Social media outreach department & $\begin{array}{l}\text { Existence or non-existence of a specific department for social } \\
\text { media outreach }\end{array}$ & Organization \\
\hline Level of experience with Twitter & Age of the account (in months) & Twitonomy \\
\hline \multicolumn{3}{|c|}{ ACCOUNT ACTIVITY } \\
\hline Language of post & Adequacy of the main posting language for the target audience & Twitonomy \\
\hline Number of follows & Number of users followed by each profile & Twitonomy \\
\hline Number of tweets & Number of Twitter posts (not including retweets) & Twitonomy \\
\hline Number of retweets & Number of retweets made by the profile to other users & Twitonomy \\
\hline Number of replies & Number of replies to other users' comments on profile posts & Twitonomy \\
\hline Number of favorites & Number of likes or favorites given by the profile to other users & Tinfoleak \\
\hline Average tweets per day & Arithmetic mean of the number of profile posts in a day & Twitonomy \\
\hline \multicolumn{3}{|c|}{ ACCOUNT IMPACT } \\
\hline Number of followers & Number of users following the profile & Twitonomy \\
\hline $\begin{array}{l}\text { Number of tweets retweeted by } \\
\text { other users }\end{array}$ & Number of profile posts obtaining at least one retweet from another user & Twitonomy \\
\hline Total retweets received & $\begin{array}{l}\text { Sum of all retweets obtained by all the profile's posts in the } \\
\text { period analyzed }\end{array}$ & Twitonomy \\
\hline $\begin{array}{l}\text { Number of tweets favorited by } \\
\text { other users }\end{array}$ & $\begin{array}{l}\text { Number of profile posts obtaining at least one like or favorite from } \\
\text { another user }\end{array}$ & Twitonomy \\
\hline Total favorites received & Sum of all favorites obtained by all profile posts & Twitonomy \\
\hline Efficiency & Average number of retweets and favorites received for each profile post & Twitonomy \\
\hline Hashtag total & Number of hashtags used by the profile & Twitonomy \\
\hline Mentions made by the profile & Number of times the profile named another user in any of its posts & Tinfoleak \\
\hline Mentions received & $\begin{array}{l}\text { Number of times the profile was named by another user in any of } \\
\text { its posts }\end{array}$ & Tinfoleak \\
\hline
\end{tabular}

Several questionnaires were prepared for each cluster in order to determine the relationships between the large numbers of elements of our complex network. These questionnaires facilitated the understanding of the problem for the expert who simply marked with a " $\sqrt{ }$ " if she identified the influence of the criterion in the row on the criterion in the column, and otherwise left it blank. Table 2 shows the correlation matrix of the model which summarizes all the influences identified by the expert. Note that the diagonal of the matrix is shaded in grey because no element of a model can have an influence on itself. As can be seen in the matrix, all the criteria influenced the profiles analyzed and, at the same time, all the profiles influenced all the criteria. 
Table 2. Correlation matrix of model elements.

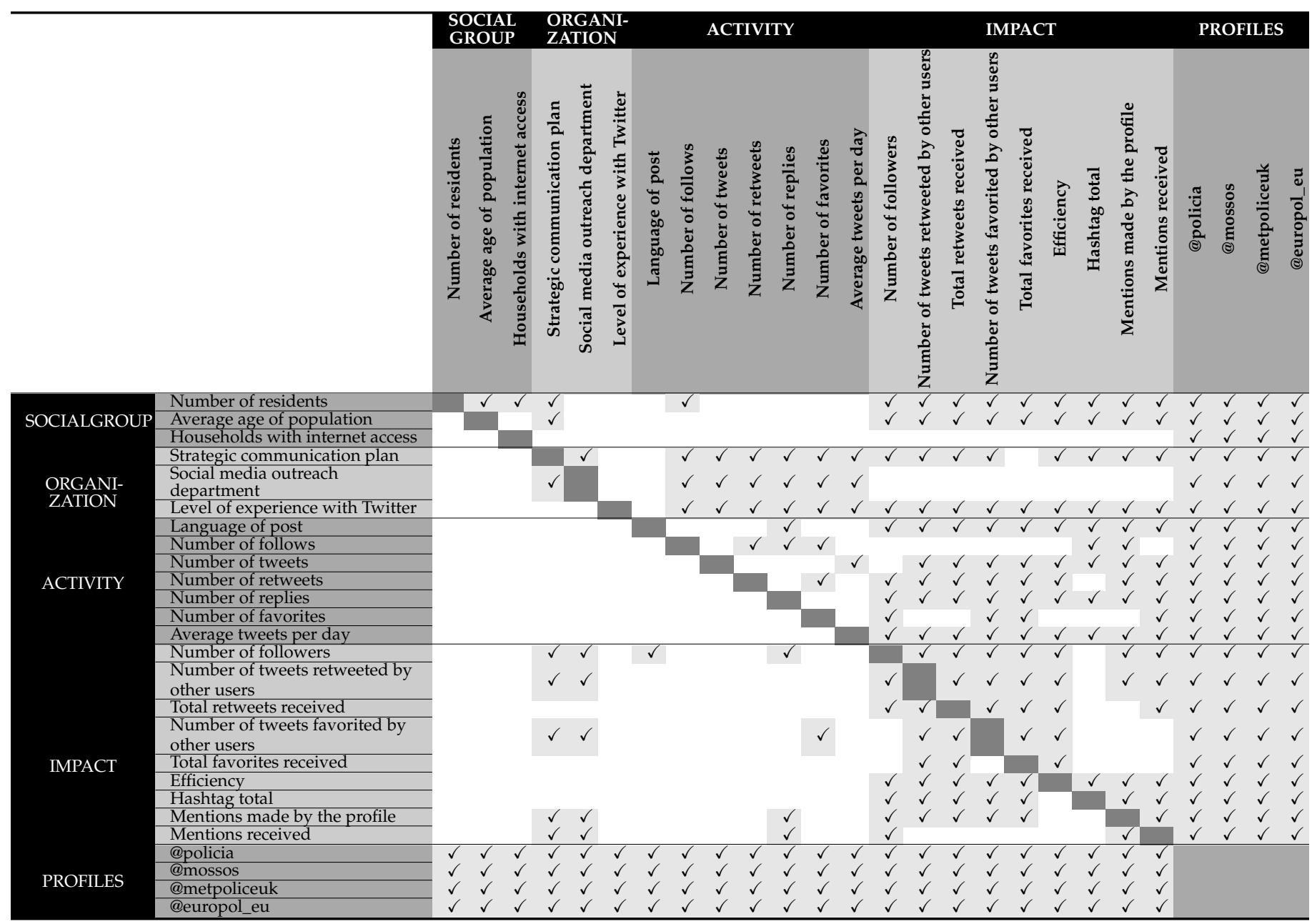

Once the expert completed all the questionnaires and Table 2 was built, critical information was available to graphically represent the problem as a network. Figure 2 shows the network of the problem in which different types of relationships between the components of the model can be identified: feedback relationships (i.e., some element of a given cluster has an influence on some element of the same cluster) and external relationships (at least one element of a cluster is related to some element of another cluster). The former appeared in all the clusters of the model (with the exception of the "Profiles" cluster, because, as explained above, in the ANP method all the criteria affected the alternatives and vice versa). For example, in the case of the "Impact" cluster, it was apparent that the criterion Number of tweets published influenced the Average number of tweets/day. For the external relationships between components, the network model shows that: (i) the cluster "Social and technological environment" was only affected by the special case of the cluster "Profiles", but influenced all other clusters; (ii) the cluster "Account Activity" was influenced by elements of all other clusters, but only influenced "Account Impact" because, according to the expert's assessment, the higher the intensity of the activity, the higher the impact of the profile; (iii) the "Organization" cluster was affected by "Social and technological environment" and "Impact of the account" because once a certain level of impact on the population is reached, the organization should likely consider the development of an official communication plan or the formal establishment of a social media dissemination department. 


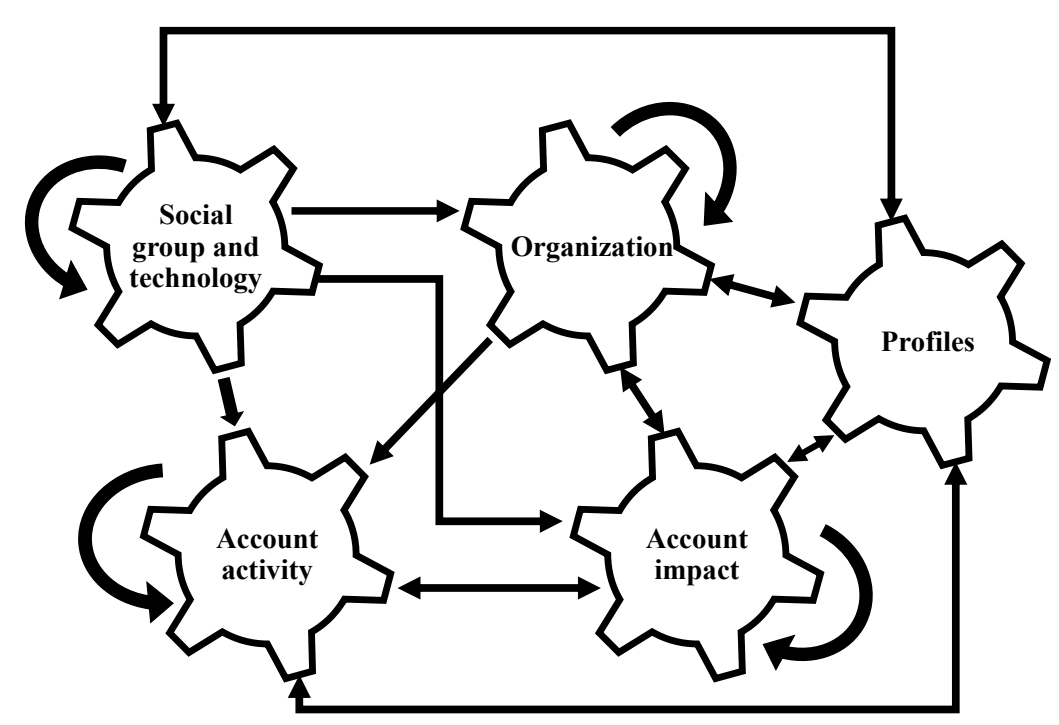

Figure 2. Network model of the proposed question.

A more exhaustive analysis of Table 2 provided valuable information about the model and the interactions between the criteria and the clusters. Beyond establishing a relationship of interdependence between criteria of a similar nature within the clusters, as in the case of Number of inhabitants and Average population age in the "Environment" cluster, there were inter-cluster relationships (or a lack thereof) that were a priori revealing. Such was the case, for example, with the relationships established between all of the criteria of the "Organization" cluster with all of the criteria of the "Activity" cluster, except for Language. Continuing with this cluster, and analyzing its relationships with the criteria of the "Impact" cluster, Degree of Experience was the criterion that demonstrated the most interrelationships, because it had a direct relationship with all the criteria. The "Activity" cluster appears to not present many interrelationships between the criteria of which it was comprised. In fact, only the Number of people followed had an interaction with three of the six criteria that made up the cluster. Continuing with the "Activity" cluster, Language and Average number of tweets per day were the criteria that showed the most relationships with the "Impact" cluster. As for the "Impact" cluster, unlike the "Activity" cluster, a greater degree of interrelationship was found between the criteria of the cluster. In fact, the "Impact" cluster had dependency relationships with most of the other criteria in the model, which suggested that they would have a high level of importance in their assessment. Regarding the inter-cluster relationships of this cluster, Efficiency was the only criterion related to all the criteria in its own cluster, with the Number of followers the least interrelated.

\subsection{Relative Significance of the Criteria and Clusters}

Once the problem has been modeled as a network, the expert evaluates all the elements of the model through paired comparisons. Given the complexity of filling in all the paired comparison matrices using Saaty's fundamental scale, the expert's judgments were collected through questionnaires where she had to indicate which criterion is more important. Figure 3 shows an example of these questionnaires, where the expert had to answer the question "From a social marketing and the use of Twitter as a communication tool point of view, which factor is most important?" To answer these questionnaires, she had to indicate with an $\mathrm{X}$ how important the factor on the left was compared to the one on the right. Depending on the degree of importance, a value of 1-9 on the Saaty scale corresponded to it. Thus, if the two factors were equally important, a value of 1 was assigned. On the other hand, if the factor on the left was significantly more important than the one on the right, a value of 9 was assigned. Conversely, if the factor on the left was much less important (or, in other words, if the one on the right was much more important), the reciprocal value $1 / 9$ corresponded to it. 


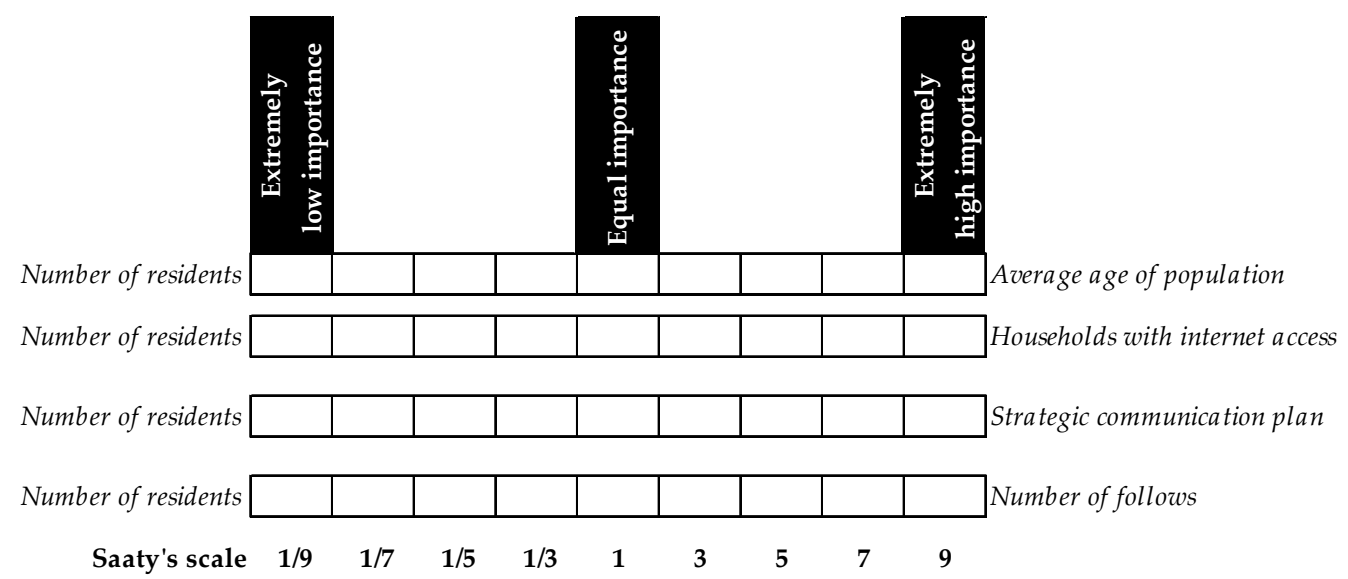

Figure 3. Example of a questionnaire.

Finally, the calculation of the weighted supermatrix and the limit supermatrix leads to the determination of the relative importance of the elements of the network. Starting from the top level in the model, Figure 4 shows the importance of each cluster in the problem according to judgments made by the communication expert. The relevance of the "Account Impact" cluster over the rest of the clusters was evident, with a significantly higher weight $(46 \%)$. This result was not surprising, accounting for the fact that this study analyzed Twitter from a marketing standpoint, but not as a tool for selling a product or service. It was analyzed, rather, as a tool for reaching the target audience for different social campaigns and influencing their behavior. This cluster was followed by the "Profiles" cluster (31\%) and the "Account Activity" cluster (14\%), as it was necessary for these organizations to use the social network to disseminate messages that subsequently achieved this reaction. Finally, the clusters "Social and technological environment" and "Organization" had minor influences ( $4 \%$ and $5 \%$, respectively).

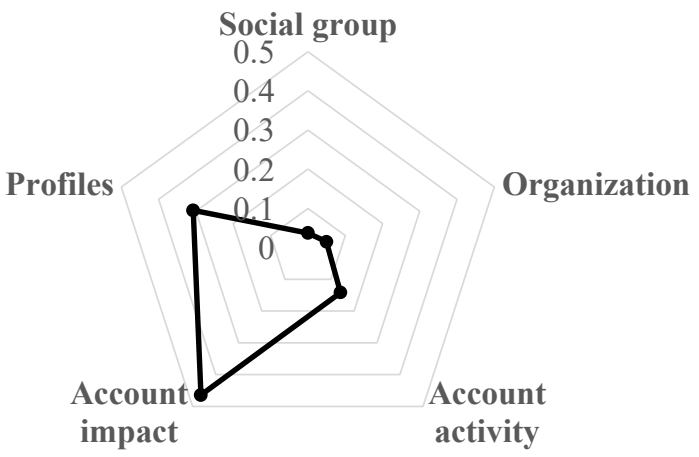

Figure 4. Relative significance of the clusters after the application of ANP and the normalization of results.

By analyzing the results obtained per criteria, Figure 5 similarly shows the set of criteria analyzed in the study and their relative importance in the model based on the assessment of the expert. The figure shows that the factors with the greatest importance for the model were, on the one hand, those related to the impact generated by the account itself as measured through the criteria Number of followers, Total retweets received and Efficiency along with, and, on the other hand, those related to interactions with other users measured by Mentions received. Therefore, both the "Impact" cluster and some of the criteria comprising it (Number of followers, Total retweets received, Efficiency and Mentions received) were precisely those which determined the success of the account when used to communicate messages in the field of social marketing. 


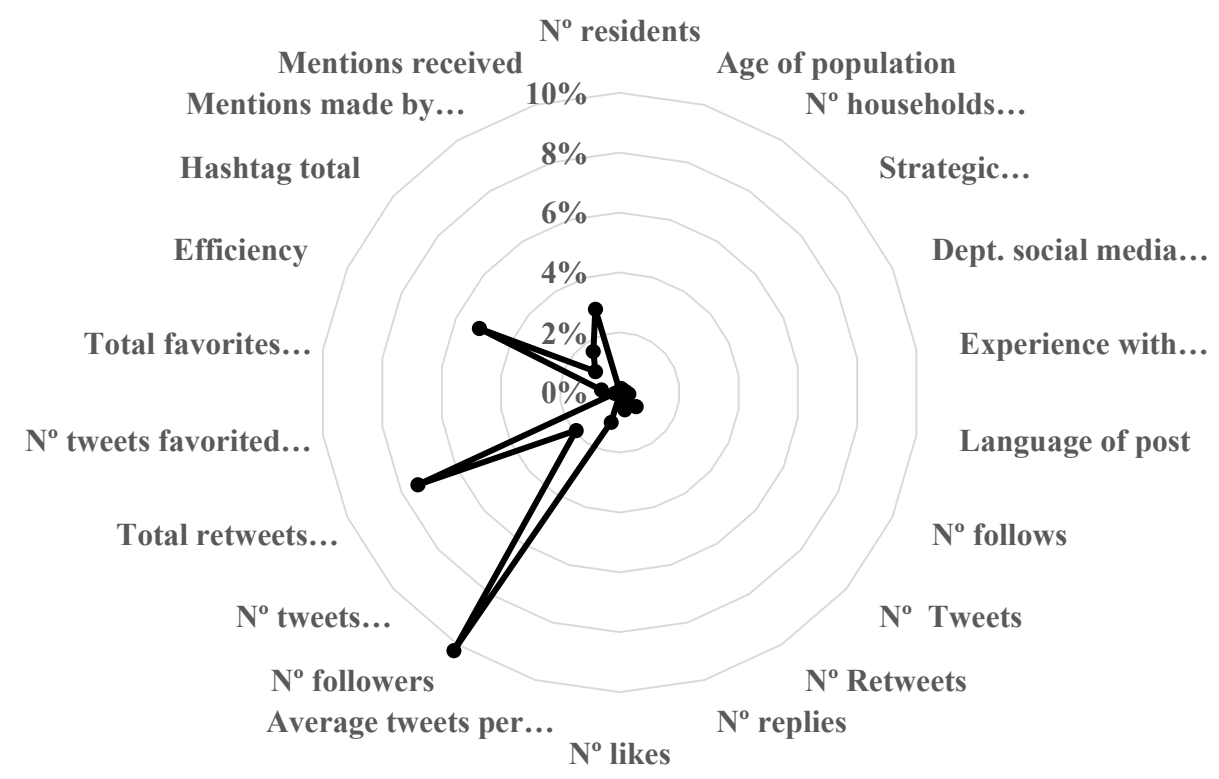

Figure 5. Relative significance of the criteria in the model after the application of ANP and the normalization of results.

In addition to the relative importance of the criteria in the problem as a whole, the ANP model also provided information on the relative weight of each criteria within its cluster. The main results obtained were as follows:

The "Social and technological environment" cluster had little relevance to the problem posed. At the time of the study, the vast majority of households had Internet access. Additionally, social media had no geographical limitations. There were no borders, and the publications of Spanish profiles could reach and have an impact anywhere in the world. The only criterion that was of some importance in this cluster was the age of the population, because the higher the percentage of the population that was of an age to use the social network, the greater the possibility of reaching the public through this medium.

For the "Organization" cluster, the years of experience in the social network (Degree of experience) and the growing use of the same led all the organizations within the study to have a Strategic Communication Plan that determined the specific actions to implement and the objectives to be achieved. However, not all of them had a department devoted to social media outreach, its requirement being questionable depending on the model. This could be explained by the fact that, despite not having a formal department, there were experts in charge of communication in social media and, therefore, having a strategic plan that defined the guidelines to be followed appeared more important and necessary to ensure the success of the strategy.

In the "Activity" cluster, the most important criteria were those referring to the intensity of publication (measured through the criterion Average number of tweets/day) and the Number of tweets. The greater the number of publications and the more frequently they were published, the greater the number of opportunities to have an impact on the target audience. Generally, profiles should be active without saturating their audience. Following these criteria, the Number of retweets and the Number of replies were important, as they were a way of initiating interactions or conversations with the target audience. On the other hand, the Number of followers or the Number of favorites of other users added little value to the problem as a whole.

For the "Impact" cluster, the most important criteria were the Number of followers and the Total number of retweets received. Obviously, the more followers an account had, the greater the direct reach of the publications. Additionally, retweets allowed the publication to reach users who did not necessarily follow the profile, and, therefore, the number of retweets became a critical impact criterion. These criteria were followed by the Efficiency of the account, which related the impact achieved in terms of retweets and the favorites per 
post, and Mentions Received, which made the conversation between the profile and another user visible to the followers of the user. Total hashtags and the Number of tweets marked as favorites by others were not, according to the expert, remarkable criteria on the impact on the account.

\subsection{Profile Identification for Best Use of Twitter as a Social Marketing Communication Channel}

The profile valuations produced the results shown in Figure 6, below. The figure shows the relative weight of each profile, which became an indicator of the success of the account in using Twitter for social communication. As such, the profiles that obtained a higher weight after the application of the model were the profiles that stood out positively in the most relevant criteria in the problem, i.e., those related to the "Impact" cluster. The figure shows that the profile of the National Police (@Policia) obtained the best rating, followed by the London Metropolitan Police (@metpoliceuk) and the Mossos de Esquadra (@mossos), leaving Europol (@europol_eu) as the worst rated.

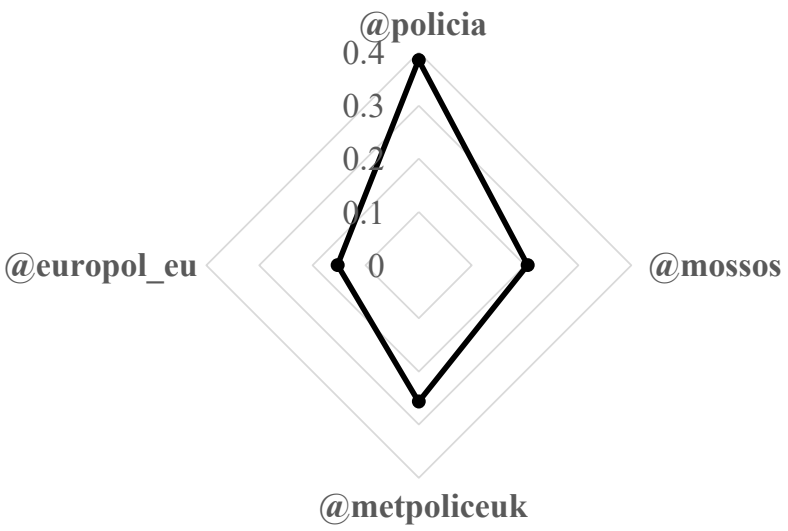

Figure 6. Relative significance of the analyzed profiles after the application of ANP and the normalization of results.

\section{Discussion}

This paper serves to fill the research gap highlighted in the literature review and to offer a series of guidelines that could be used by public organizations for their social marketing communication strategies on Twitter. Our analysis centered around four aspects, named as clusters in the model: (i) the social and technological environment, (ii) the characteristics of the organization in terms of communication, (iii) the activity of the account, and (iv) the impact achieved by the account. An MCDM method, concretely the ANP method, was employed, which made it possible to model the problem as a network and to capture the interrelationships existing between the factors of the problem. In this way, a complex model was produced, one that better represents the real problem using paired comparisons between factors to evaluate and compare the criteria included in the model according to the scale proposed by Saaty.

The results of the ANP method lead to the identification of the most relevant factors, i.e., the key factors for an efficient use of social media as a channel for disseminating social marketing messages. It is important to highlight that the results of our research may be used by public organizations as a guide for the development of communication social marketing strategies through Twitter with one objective: social welfare (see Figure 7). According to the results of this study, the "Account Impact" cluster had the greatest relevance, and within it the criteria Number of followers, Total retweets received, Efficiency and Mentions received. However, the impact of a profile depended to a large extent on "Account Activity", and in this cluster it was found that Average number of tweets/day and Number of tweets were the most relevant factors. According to the obtained results, the "Social Group and Technology" cluster did not hold significant weight, although within this cluster attention should be paid to the criterion Population age, as it was directly related to the users of social media. For the "Organization" 
cluster, the most significant factor was the existence of a Strategic communication plan, above and beyond the existence of a social media outreach department that did not have a defined strategic plan.

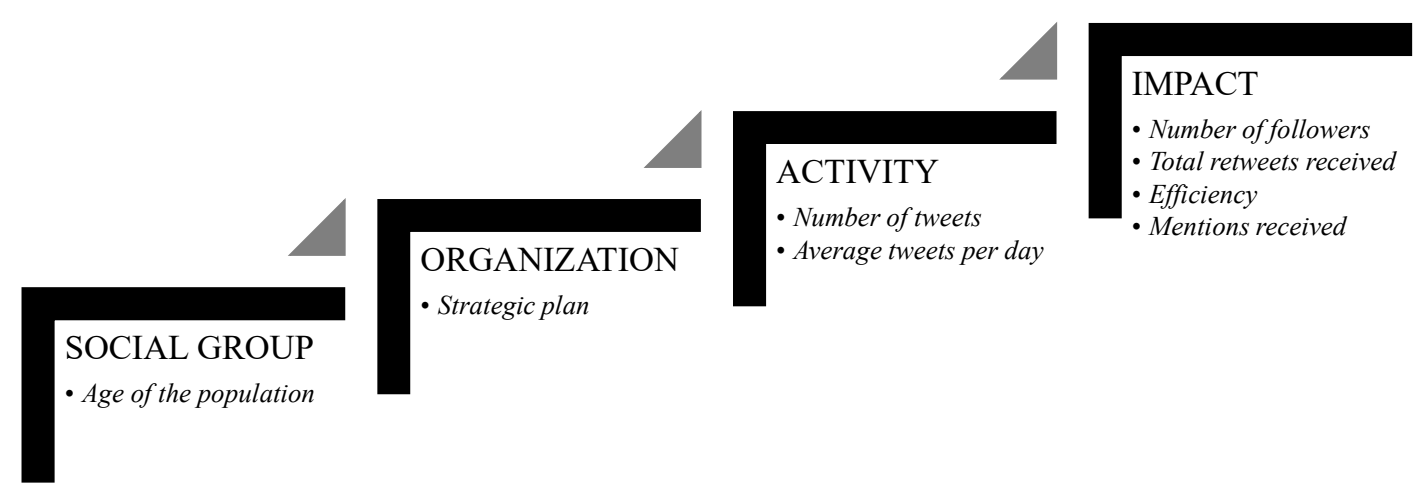

Figure 7. Most significant factors in the design of communication strategies for social media marketing using Twitter.

In addition, to identify the most important factors in the use of Twitter as a social marketing media, the results of this study allowed for the identification of which organization achieved the greatest relative impact on Twitter. The profile of the National Police (@policia) obtained the best results. Further analysis of the characteristics of this profile showed that the National Police had more followers and that most of its publications went viral.

\section{Conclusions and Future Lines of Work}

New technologies and the expansion of social media affected social marketing in a way similar to their effect on commercial marketing, which actively employed communication strategies offering sustainable results in order to be effective and efficient. The objective of social marketing is to contribute, in some way, to social welfare, including the concept of sustainable development. However, it also seeks to provoke a reaction in the behavior of the target audience. It must therefore seek new means of accessing a society that is already saturated with information in order to achieve its objectives. Many studies existed on the use of social media for commercial purposes but, in the field of social marketing, studies were practically non-existent. The shortage of published research on this subject did not reflect the extensive and growing use of social media for social purposes by public administrations. Twitter became one of the main channels of communication between social marketing program providers and their target audience of citizens. These social media allowed for the interaction between both parties, favoring citizen participation and communication in real time, and without time or geographical limitations. In addition, they allowed public administrations to project an image of commitment and transparency to citizens and were a low-cost means of mass dissemination. Although social media offered many advantages to social marketing, the lack of analysis for their efficient use limited the growth and expansion of this type of marketing in increasingly digitalized and changing societies. In addition to the lack of research, there was also a lack of digital communication experts among the teams employed by public bodies who were in charge of managing the accounts and profiles of the different social media. Public administrations had to adapt, the same as any other brand in the market, to an increasingly demanding public. The lack of knowledge and resources often resulted in misguided communication strategies that moved away from the objective of social marketing. Therefore, the results of the study give a double contribution to the knowledge in the field. On the one hand, from a practical point of view, they identify the relevant factors when using Twitter as a social marketing communication tool. On the other hand, from a methodological point of view, it is the first time that the ANP method is used in this context, which allows us to include in the model not only an important number of factors (both qualitative and quantitative) but also 
the interrelationships that exist between them. The results of this research showed that, despite their experience on Twitter, some of the profiles analyzed continued to concentrate their efforts in an inefficient way, failing to achieve the impact they expected for their publications. It is precisely at this point in the process that the model proposed in this article could serve as a guide and a practical tool with which administrations could design or adapt their social communication strategies on Twitter based on those factors with a higher importance and leaving aside those that, although they may consume resources, do not lead to the expected results. As a consequence, administrations could influence more users in terms of social welfare and sustainability. Of the four profiles analyzed in this research, the one of the National Police (@policia) obtained the best results. However, information was not available on the reasons that led users to follow the profile or retweet its publications. The results of the model showed that the intensity of publication (Average tweets /day) was a determining factor for greater impact. However, this study has some limitations that must be taken into account when interpreting the results obtained, and which in turn open up new lines of future work. The National Police profile did not necessarily have the greatest impact just because it published more frequently and was more active on the social network, since the mere fact of disseminating publications was not enough to necessarily reach the target audience. The content, structure and language of the messages were fundamental and should therefore also be addressed from a social marketing point of view in order to complete this study.

Further research may include a qualitative study in order to determine whether this impact was due to the appropriateness of the content, the quality of the messages disseminated, the time of publication, etc. A proposal for future work to overcome the limitations of this study is to carry out an analysis extension from a qualitative point of view after determining which factors warrant further attention.

Author Contributions: Conceptualization, E.G., E.B., C.S.-M., L.C.-D.; methodology, B.B.-G., E.G., E.B.; software, E.G.; validation, B.B.-G., E.G., E.B; formal analysis, B.B.-G., E.G., E.B.; investigation, E.G.; L.C.-D.; data curation, B.B.-G., E.G., E.B.; writing-original draft preparation, E.G., C.S.-M., E.B, L.C.-D.; writing-review and editing, E.G.; C.S.-M., E.B., L.C.-D.; visualization, E.G., L.C.-D.; supervision, E.G., E.B., C.S.-M. All authors have read and agreed to the published version of the manuscript.

Funding: This research received no external funding.

Institutional Review Board Statement: Not applicable.

Informed Consent Statement: Not applicable.

Data Availability Statement: Not applicable.

Acknowledgments: The authors would like to express their gratitude to the experts who have selflessly participated in this work. In addition, we would like to express our gratitude to the anonymous referees of this paper, whose comments have really helped to improve the quality of our work. All errors remain ours.

Conflicts of Interest: The authors declare no conflict of interest.

\section{References}

1. United Nations. Transforming our world: The 2030 Agenda for Sustainable Development, Resolution adopted by the General Assembly on 25 September 2015. Available online: https://www.un.org/ga/search/view_doc.asp?symbol=A/RES/70/1\&Lang= E (accessed on 1 June 2021).

2. Hartley, J. Innovation in governance and public services: Past and present. Public Money Manag. 2005, 25, 27-34.

3. Criado, I.; Rojas-Martín, F. Casos de éxito en redes sociales digitales de las administraciones públicas. In Casos de Éxito en Redes Sociales Digitales de las Administraciones Públicas; Escola d'Administració Pública de Catalunya: Barcelona, Spain, 2015. [CrossRef]

4. Negrete-Huelga, K.; Rivera-Magos, S. Estrategias de comunicación en redes sociodigitales desde la práctica del gobierno abierto. Cuadernos.Info 2018, 42, 183-196. [CrossRef]

5. Brundtland, G.H. Report of the World Commission on Environment and Development: Our Common Future. 1987. Available online: http: / / www.un-documents.net/wced-ocf.htm (accessed on 27 May 2021).

6. Ballestar, M.T.; Cuerdo-Mir, M.; Freire-Rubio, M.T. The concept of sustainability on social media: A social listening approach. Sustainability 2020, 12, 2122. [CrossRef] 
7. Huang, L.; Clarke, A.; Heldsinger, N.; Tian, W. The communication role of social media in social marketing: A study of the community sustainability knowledge dissemination on LinkedIn and Twitter. J. Market. Anal. 2019, 7, 64-75. [CrossRef]

8. Ilieva, R.T.; McPhearson, T. Social-media data for urban sustainability. Nat. Sustain. 2018, 1, 553-565. [CrossRef]

9. Pilař, L.; Kvasničková Stanislavská, L.; Pitrova, J.; Krejčí, I.; Ticha, I.; Chalupova, M. Twitter analysis of global communication in the field of sustainability. Sustainability 2019, 11, 6958. [CrossRef]

10. Porcelli, A. El valor de las redes sociales en el progreso de los objetivos de desarrollo sostenible. Lex SOCIAL: Rev. Derechos Soc. 2020, 10, 595-630. [CrossRef]

11. Dovleac, L. The role of new communication technologies in companies' sustainability. Bull. Transilv. Univ. Braşov. Ser. V Econ. Sci. 2015, 8, 33-40.

12. Taneja, S.; Toombs, L. Putting a face on small businesses: Visibility, viability, and sustainability the impact of social media on small business marketing. Acad. Mark. Stud. J. 2014, 18, 249.

13. Minton, E.; Lee, C.; Orth, U.; Kim, C.H.; Kahle, L. Sustainable marketing and social media: A cross-country analysis of motives for sustainable behaviors. J. Advert. 2012, 41, 69-84. [CrossRef]

14. Feeney, M.; Welch, E. Implementing information and communication technologies (ICT) in public organizations: The mediating effects of organization routineness and centralization on ICT and managerial outcomes. In Proceedings of the Event 14th Annual International Digital Government Research Conference: From E-Government to Smart Government, Quebec City, QC, Canada, 17 June 2013. [CrossRef]

15. Alvarenga, A.; Matos, F.; Godina, R.; Matias, J.C.O. Digital transformation and knowledge management in the public sector. Sustainability 2020, 12, 5824. [CrossRef]

16. Yi, M.; Oh, S.G.; Kim, S. Comparison of social media use for the US and the Korean governments. Gov. Inf. Q. 2013, 30, 310-317. [CrossRef]

17. Mergel, I. Introducing Open Collaboration in the Public Sector: The Case of Social Coding in Github; European Group of Public Administration: Speyer, Germany, 2014. [CrossRef]

18. Criado, J.I.; Rojas-Martín, F.; Gil-García, J.R. Enacting social media success in local public administrations: An empirical analysis of organizational, institutional, and contextual factors. Int. J. Public Sect. Manag. 2017, 30, 31-47. [CrossRef]

19. Ministerio de Política Territorial y Función Pública, Gobierno de España. Informe IRIA 2018. In Las Tecnologías de la Información y las Comunicaciones en la Administración Local; Ministerio de Política Territorial y Función Pública: Madrid, Spain, 2018.

20. Rojas-Martín, F.; Criado, I. Estrategias y realidades de las redes sociales en las administraciones públicas. Análisis desde una perspectiva institucionalista. Innovar: Revista De Ciencias Administrativas y Sociales 2015, 25, 45-62. [CrossRef]

21. DePaula, N.; Dincelli, E.; Harrison, T.M. Toward a typology of government social media communication: Democratic goals, symbolic acts and self-presentation. Gov. Inf. Q. 2018, 35, 98-108. [CrossRef]

22. Twizeyimana, J.D.; Andersson, A. The public value of E-Government-A literature review. Gov. Inf. Q. 2019, 36, 167-178. [CrossRef]

23. Kligler-Vilenchik, N. Alternative citizenship models: Contextualizing new media and the new "good citizen". New Media Soc. 2017, 19, 1887-1903. [CrossRef]

24. Mickoleit, A. OECD working papers on public governance. In Social Media use by Governments: A Policy Primer to Discuss Trends, Identify Policy Opportunities and Guide Decision Makers; OECD Publishing: Paris, France, 2014; Volume 26. [CrossRef]

25. Chun, S.; Luna, L. Social media in government. Gov. Inf. Q. 2012, 29, 441-445. [CrossRef]

26. Gil-García, J.R. Enacting Electronic Government Succes: An Integrative Study of Government-Wide Websites, Organizational Capabilities, and Institutions; Springer Science \& Business Media: New York, NY, USA, 2012. [CrossRef]

27. Generalitat de Cataluña. Manual de Los Gobiernos en Twitter; Generalitat de Cataluña: Cataluña, Spain, 2017.

28. Fernández Guerra, C. @Policia: Las Historias de un Éxito; Alfaguara: Madrid, Spain, 2014.

29. Guijarro, E.; Santandreu Mascarell, C.; Canós-Darós, L.; Díez-Somavilla, R.; Babiloni, E. Técnicas multicriterio aplicadas a las redes sociales en el sector público: El uso de Twitter por distintos perfiles de fuerzas y cuerpos de seguridad. Rev. Lat. Comun. Soc. 2018, 73, 1412-1427. [CrossRef]

30. Del Interior, M. La Policía Nacional recibe el Premio Ciudadanía a la Calidad e Innovación en la Gestión Pública 2014 por su labor en redes sociales, October. 2015. Available online: http:/ / www.interior.gob.es/prensa/noticias/-/asset_publisher/GHU8 Ap6ztgsg/content/id/4882741 (accessed on 25 May 2021).

31. Meijer, A.J.; Torenvlied, R. Social media and the new organization of government communications: An empirical analysis of Twitter usage by the Dutch police. Am. Rev. Public Adm. 2016, 46, 143-161. [CrossRef]

32. Brainard, L.; Edlins, M. Top 10 US municipal police departments and their social media usage. Am. Rev. Public Adm. 2015, 45, 728-745. [CrossRef]

33. Grimmelikhuijsen, S.G.; Meijer, A.J. Does Twitter Increase Perceived Police Legitimacy? Public Adm. Rev. 2015, 75, 598-607. [CrossRef]

34. Castillo, G.P. Redes sociales institucionales de éxito: Los casos de@ policia y@ guardiacivil en España. Opción Rev. Cienc. Hum. Soc. 2016, 12, 85-109.

35. Fowler, B.M. Stealing thunder and filling the silence: Twitter as a primary channel of police crisis communication. Public Relat. Rev. 2017, 43, 718-728. [CrossRef] 
36. Rojas De, F.L.; Macías Prada, J. Autogestión, emprendimiento social e innovación social: Un análisis de contenidos publicados en twitter. TEC Empresarial 2019, 13, 42-57. [CrossRef]

37. Rodríguez-Andrés, R.; López-García, J.M. Aproximación al uso de las redes sociales por las fuerzas y cuerpos de seguridad en España en perspectiva internacional. Index Comun. 2019, 9, 127-148.

38. Tejería Estébanez, A. Metáforas y emociones en el discurso institucional en redes sociales: Los mensajes en Facebook y Twitter de la Policía Nacion. Dipósit digital de la Universitat de Barcelona. 2020. Available online: http:/ /hdl.handle.net/2445/171046 (accessed on 24 May 2021).

39. Bani, S. La comunicación institucional en las redes sociales: Los cuerpos de seguridad en Twitter. Cuad. AISPI 2020, 16, 63-86. [CrossRef]

40. Bloom, P.; Novelli, W. Problems and challenges in social marketing. J. Mark. 1981, 45, 79-88. [CrossRef] [PubMed]

41. Kotler, P. Social Marketing: Strategies for Changing Public Behaviour; SAGE Publications: Thousand Oaks, CA, USA, 2002.

42. Dann, S. Redefining social marketing with contemporary commercial marketing definitions. J. Bus. Res. 2010, 63, 147-153. [CrossRef]

43. Romero, C. Teoría de la Decisión Multicriterio: Conceptos, Técnicas y Aplicaciones; Alianza Editorial: Madrid, Spain, 1993.

44. Muruganantham, A.; Gandhi, G.M. Framework for social media analytics based on multi-criteria decision making (MCDM) model. Multimed. Tools Appl. 2019, 79, 1-15. [CrossRef]

45. Hung, Y.H.; Huang, T.L.; Hsieh, J.C.; Tsuei, H.J.; Cheng, C.C.; Tzeng, G.H. Online reputation management for improving marketing by using a hybrid MCDM model. Knowl. Based Syst. 2012, 35, 87-93. [CrossRef]

46. Wang, Y.L.; Tzeng, G.H. Brand marketing for creating brand value based on a MCDM model combining DEMATEL with ANP and VIKOR methods. Expert Syst. Appl. 2012, 39, 5600-5615. [CrossRef]

47. Saaty, T. The Analytic Network Process: Decision Making with Dependence and Feedback; RWS Publications: Pittsburgh, PA, USA, 1996.

48. León-Gross, T.A.; Rivera-Hernández, A.; Redondo-Escudero, M. International correspondents in Spain facing government and information sources. Evaluation of problems by analytic hierarchy process (AHP). EPI 2018, 27, 813-821. [CrossRef]

49. Saaty, T. Decision making-The analytic hierarchy and network processes (AHP/ANP). J. Syst. Sci. Syst. Eng. 2004, 13, 1-35. [CrossRef]

50. Saaty, T.; Vargas, L. Decision Making with the Analytic Network Process; Springer Science \& Business Media LLC: New York, NY, USA, 2006. [CrossRef]

51. Saaty, T. The Analytic Hierarchy Process; RWS Publications: Pittsburgh, PA, USA, 1980. 